\title{
The Pre-Vesalian Kidney: Gabriele Zerbi, 1445-1505
}

\author{
Natale Gaspare De Santo ${ }^{a}$ Carmela Bisaccia ${ }^{a}$ Rosa Maria De Santo ${ }^{a}$ \\ Alain Touwaideb \\ ${ }^{a}$ 1st Chair of Nephrology, Second University of Naples, Italy, and bepartment of History of Science, \\ University of Oklahoma, Norman, Okla., USA
}

\section{Key Words}

Gabriel Zerbi, philosopher, anatomist, physician . Pre-Vesalian anatomy. Gerentocomia. De Cautelis medicorum - Liber anatomiae

\begin{abstract}
Gabriel Zerbi was born in Verona in 1445 and died in Dalmatia in 1505. He was professor of philosophy in Padua at the age of 22, and moved to Bologna where he became professor of medicine and philosophy. In Rome at the time of Sixtus V and Innocentius VIII, he was archiater and professor of medicine. He completed his academic career in Padua where he worked from 1494 to 1505 with a salary of 600 florins a month. A man of vast culture, a philosopher, physician and professor of medicine, he wrote many books: (1) Questiones Metaphysicae; (2) Gerentocomia; (3) De Cautelis Medicorum; (4) Liber anatomiae corporis humani et singulorum membrorum illius; (5) De anatomia infantiis et porci ex traditione Cophonis, and (6) Libellus de preservatione corporum a passione calculosa. His contribution to anatomy was superb. Through him the discipline became the basis of modern medicine. The core of this article deals with some passages of Zerbi's chapters on the anatomy of the kidneys and bladder.
\end{abstract}

\section{KARGER}

Fax +41613061234 E-Mail karger@karger.ch www. karger.com

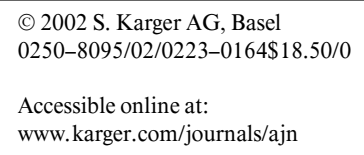

\section{Early Life}

Gabriele Zerbi is also known as Zerbi, De Zerbis, Zerbo, Zerbus, Gerbus, Gerbus and De Gerbis. In the Rotuli [1] and Libri segreti Bononiae he appears as Gerbus, Gerbus and De Gerbis. Zerbi was born in 1445 in Brinostova Street to a wealthy and noble family living in Verona. According to Facciolati he studied at the University of Padua, where on July 15, 1467, he became lecturer ad philosophiam ordinariam at the age of 22 [2]. A nomination which he held for the next 7 years during which he also obtained a medical degree.

\section{Zerbi in Bologna and Rome}

In 1475 he moved to Bologna as rotulatus ad lecturam Medicinae and continued to work there until 1483. Then he went to Rome where he became archiater and later on titular of the chair of medicine. He worked in Rome from mid 1483 to the beginning of 1494 and gained great consideration from Pope Sixtus IV and from his successor Pope Innocentius VIII (fig. 1,2) to whom he was personal physician. To the former he dedicated Questiones metaphysicae [3] and to the latter he dedicated Gerentocomia [4]. Figure 1 is a miniature which appears in the antiporta of Questiones Metaphysicae, a copy in pergamena which
Natale G. De Santo, MD

Via Pansini 5, Pad. 17

1st Chair of Nephrology, Second University of Naples

I-80131 Naples (Italy)

Tel. +3908156606650, Fax +390815666655, E-Mail nataleg.desanto@unina2.it 


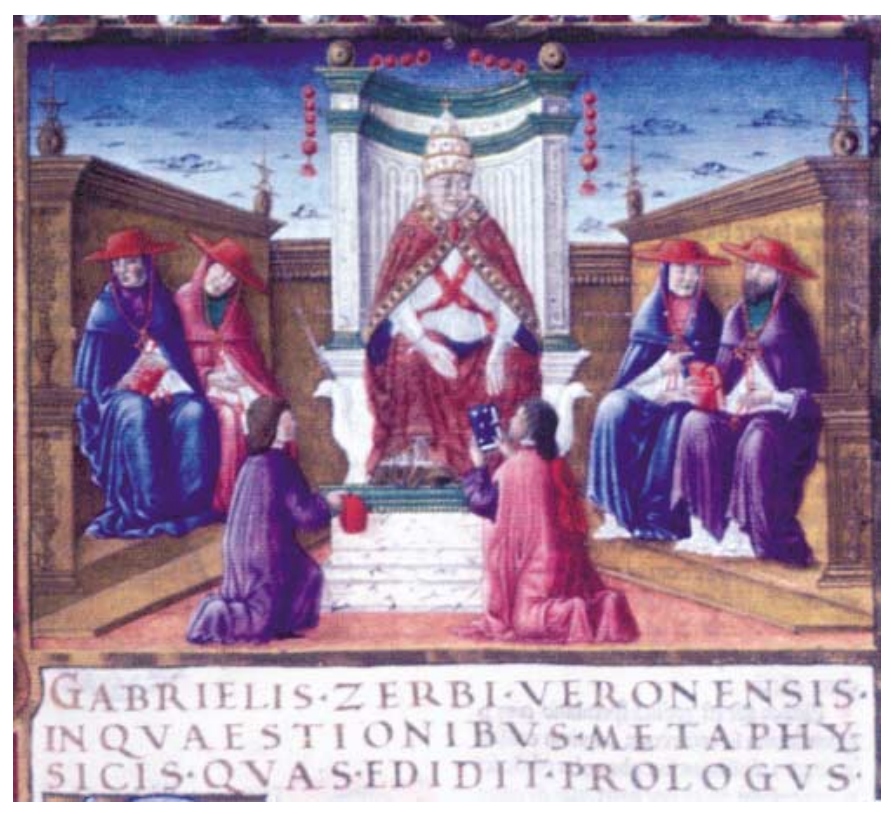

Fig. 1. A miniature appearing in the antiporta of Questiones Metaphysicae showing Pope Sixtus IV. The kneeling figure on the right is Zerbi.

represents the ceremony of dedication to Sixtus. The Pope is in the center, two cardinals are on the right and two on the left. There are two kneeling figures, and the one with a book in his hands (fig. 1,3) is Gabriel Zerbi (the only picture we have of him). The other kneeling figure has been identified as the miniaturist, as was tradition in those days.

It should be noted that Sixtus IV and Innocentius VIII (fig. 1,2) gave great impulse to anatomy. In fact, before them the Church was usually opposed to dissection. Sixtus in a brief to the rector, doctors and scholars at the University of Tübingen, dated Rome, April 4, 1482, disproved the misconception about the Church's hostility to dissection. Sixtus had studied theology and philosophy in Bologna and Padua and of course he was aware that bodies were traditionally dissected at those universities. In the brief Sixtus answers an oral quest of Giuliano della Rovere, his nephew, at the time Cardinal Bishop of Sabina. Innocentius in turn confirmed his predecessor's brief.

\section{Zerbi in Padua}

Zerbi moved to Padua on October 17, 1943, where he started his teaching position on May 6, 1494, and taught medicine there happily for 11 years.

The Pre-Vesalian Kidney:

Gabriele Zerbi, 1445-1505

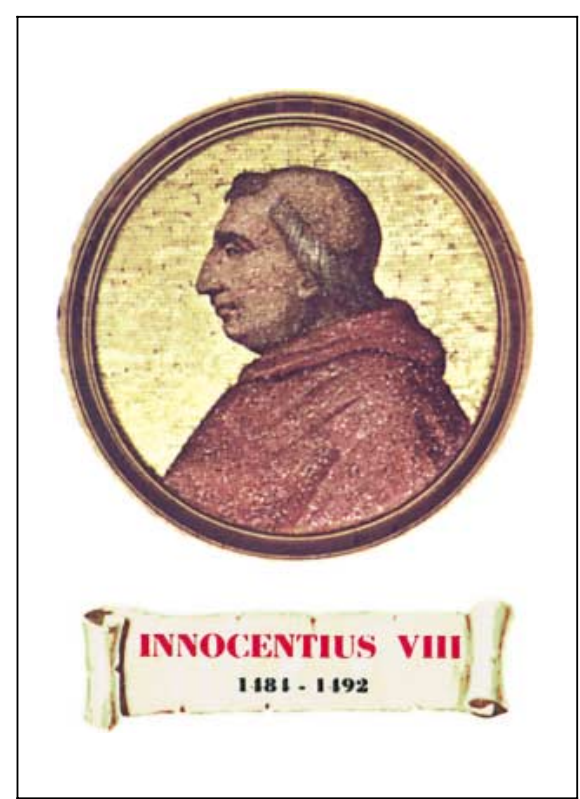

Fig. 2. Pope Innocentius VIII.

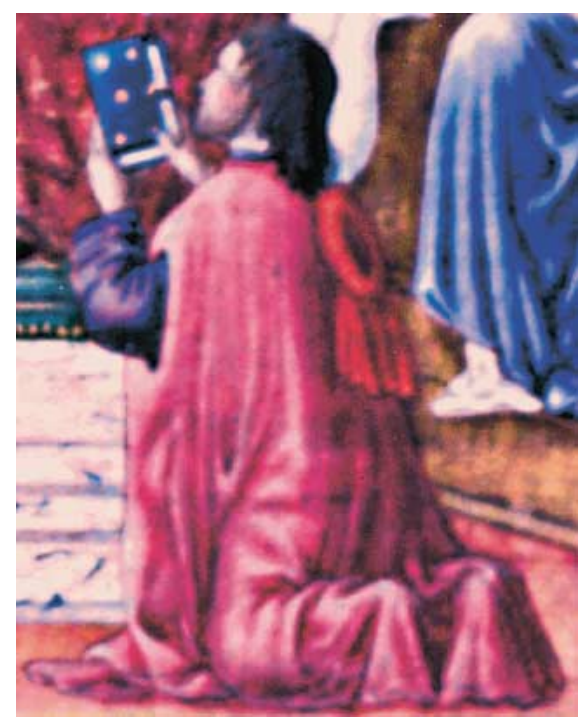

Fig. 3. Enlargement of part of figure 1 showing Zerbi.

In Padua students traditionally participated in the enrollment as well as in the control of professors even in the seond half of 1400, when at other universities this was no longer the case. On many occasions this caused the students to riot. Therefore on January 14, 1471, the Senate of 


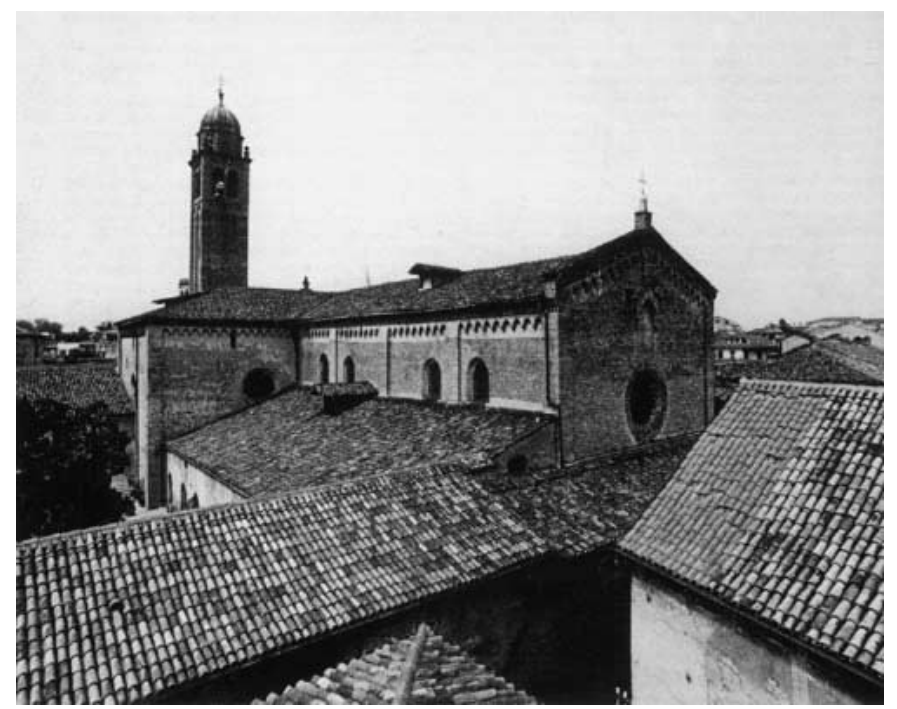

Fig. 4. The Church of Saint Francis in Padua.

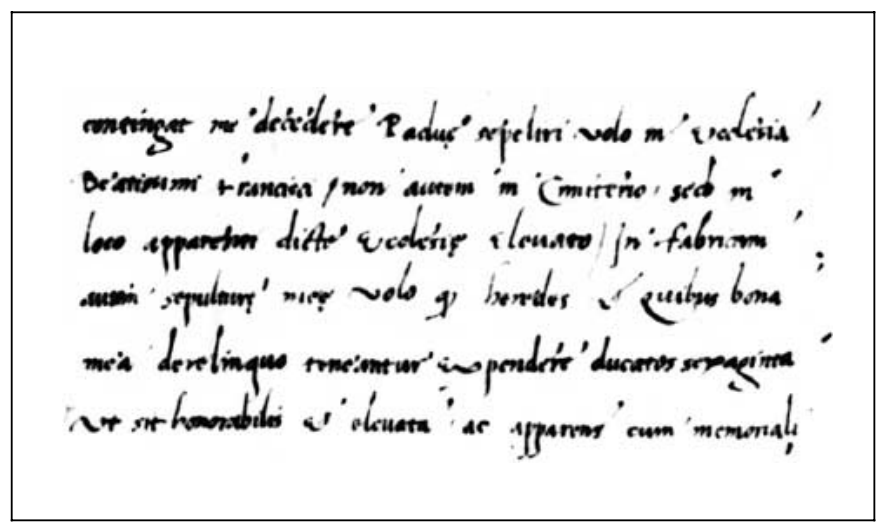

Fig. 5. The paragraph alluding to the Church of Saint Francis from Zerbi's last will.

Venice (Archivio di Stato di Venezia, Senato Terra, reg.6,f.116v,) for the first time excluded students' decisions in the call for theoretical medicine, and in 1479 excluded them from all decisions related to the control of professors of the arts. There is evidence that in accordance with the new university constitution of 1496, Zerbi and Pomponazzi were not under the students' control. From 1503 on, the students were definitely excluded from the control of all professors. However, the students still had the possibility to give suggestions, and were even allowed to participate in the delegation nominated to contact potential professors; however, all decisions in those days were made in Venice and no longer in Padua [5].

\section{The Last Will}

On October 13, 1504, Zerbi signed his last will, a document of extreme interest. In the testament, which was transcribed by Romagnoli [6] in 1967 and by Lind [7] in 1975, he asked to be buried in the Church of Saint Francis in Padua (fig. 4, 5), but not in the cemetery, perhaps out of a particular devotion to his father Franciscus. Another stronger reason is to be found in the fact that the church had developed a very important hospital with 3 infirmaries. The Church of St. Franciscus, 15th century, in downtown Padua, is located in a triangular island where the Via del Santo makes a right angle with the Via Galileo. The hypothenuse is represented by the Via San Francesco where the main entrance of the church is located. The church is a Gothic structure with three aisles. On the presbytery side there are bronzes from Bellano (1498). In his testament Zerbi left a total of sixty ducats for a funeral monument in his honor. The tomb should carry an important inscription:

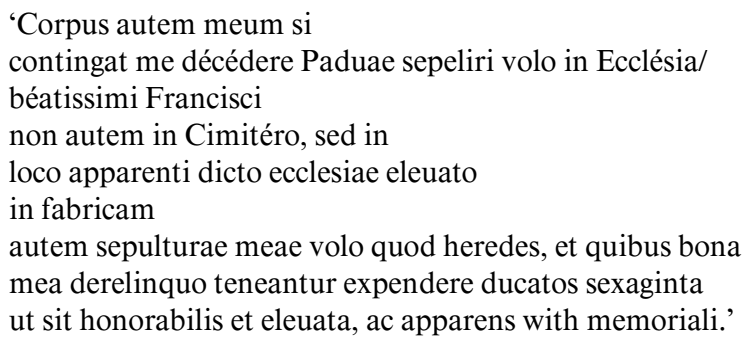

Marino Brocardo, in a letter of 1502 which appears in the prologue to Zerbi's anatomy, wrote 'Quam Patavii in te adhuc adolescente mirari cepit, Bononia in juvene stupuit, Roma in adult venerata est, ac rursum in sene Patavii in coelum laudibus effert. ... in Vaticana bibliotheca honestissimum sunt locum sortitae, et monumentum tuorum studiorum aeternitati consacrarunt' (Admired since early years in Padua, you astonished Bologna as a young man, venerated in Rome in adulthood, and now in Padua during the old age God is praised).

Rafaello Volterrano in his commentaries described Gabriel of Verona as an honor to his art, from whom in Padua they make great profit: 'Vivit Gabriel Veronensis hujus artis Decurio, qui magno Paduae profitetur'. It is interesting to note that the biographer par excellence, Ladislao Munster from Bologna, did not use adjectives

\footnotetext{
$\overline{\text { Am J Nephrol 2002;22:164-171 }}$ 
but provided a huge number of documents which are determinant in identifying and supporting the genius of Gerbus. It should be stressed that, to our knowledge, all historians of pre-Vesalian anatomy have used, missused and translated Münster's works. Without Münster's magnificent work we would be unable to observe Zerbi's heights.

A list of Gerbus' biographers is given in table 1.

\section{Zerbi's Works}

Table 2 lists Zerbi's works giving details on format, pages, type of print, publishers, editions. It is not the purpose of this article to go into detail on all his books, since our topic is the kidney. Therefore we will concentrate on the anatomy and translate some paragraphs of the chapter on the kidneys.

\section{Liber Anathomiae Corporis Humani}

Many historians of medicine consider it (fig. 6) as the last, most comprehensive human medieval anatomy [11], just preceding the new Vesalian anatomy written 40 years later. In so doing they fail to catch the spirit of the time which comes out especially from his experience with the section of animal bodies. The book which is made with $219 \frac{1}{2}$ folios is written in small Gothic type as is evident from the last page (fig. 7) including the last groups of tables, the register and also the printing house, the day of printing (Venetis per Presbyterum Bonetum locatellum Bergomensem Expensis heredum Nobilis Viri Domino Octaviani Scoti Civis modoetensis. Anno domini 1502, 9. ${ }^{\circ} \mathrm{kal}$ Januarias). This causes difficulty in reading and is one of the reasons many investigators have failed to understand it. At the beginning of the book Zerbi includes a letter from Marino Brocardo who praises him and states that 'qua nihil est hodie accuratius in terris', that is 'the book is the most accurate of our times'. The book may appear prolonged and repetitive. Sometimes good concepts are diluted with information of no value. However, as Portal stresses, Zerbi must be read carefully to understand his contribution to new anatomy.

Salvatore De Renzi who authored a significant Storia della Medicina in Italia [12], was indeed one of those historians who appreciated Zerbi's strong knowledge of animals as a basis for his abilities in human anatomy. 'Because of the scarce availability of cadavers he also sected animal bodies, thereby, he was opening the discipline of comparative anatomy. Zerbi generally follows Mondino, however on many occasions he shows that some organs had been studied more extensively by him. He reports on
Table 1. Zerbi's biographers

\begin{tabular}{ll}
\hline Major biographers & \\
Marino Sanuto il giovane & $1466-1536$ \\
Paulus Iovius & 1577 \\
Ioannes Pierrius Valerianus & 1620 \\
Jacobus Facciolati & 1757 \\
Antoine Portal & 1770 \\
Gaetano Marini & 1784 \\
Girolamo Tiraboschi & 1823 \\
Curzio Sprengel & $1826,1840,1841$ \\
Giuseppe Cervetto & 1842 \\
Salvatore De Renzi & 1845 \\
Jean François Michaud & 1755 \\
Michele Medici & 1857 \\
Umberto Dallari & 1888 \\
Adalberto Pazzini & $1946,1947,1961$ \\
Ladislao Münster & 1950,1951 \\
E. Dell'Osso & 1957 \\
José Riesco & 1964 \\
Marco Cesare Nannini & 1967 \\
Giovanni Romagnoli & 1967 \\
Levi Robert Lind & 1975 \\
Tiziana Pesenti & 1984 \\
Loris Premuda & 1965,1996 \\
David E.J. Linden & 1999 \\
\hline Minor biographers & \\
Gio. Nic. Pasquali Alidosi & 1623 \\
NFI Eloy & 1755 \\
Alberto Haller & 1774 \\
Hermann Joh. Baas & 1876 \\
Field H. Garrison & 1929 \\
August Hirsch & 1934 \\
Francesco Pellegrini & 1939 \\
Albano Corbelli & 1940 \\
Mauro Tridente & 1948 \\
Ralph H. Maior & 1959 \\
Richard Hardaway Meade & 1968 \\
Theodor Puschmann & 1971 \\
Giuseppe Ongaro & 1981 \\
François Dupuigrenet Desroussilles & 1981 \\
Marco Tullio Malato & 1994 \\
\hline & \\
\hline & \\
\hline
\end{tabular}

the various parts of human body, those in the abdomen, in the thorax and in the skull. Then he describes the limbs. He also distinguishes the chapters of the systems: osteology, angiology, myology. The last part deals with the description of the embryo. He was aware that the peritoneum covers the spermatic funicle and the testicle. He compares the structure of the intestinal organs with that of the animals, especially with those of ruminants. He anticipates Falloppia in describing the muscular structure of the gut and describes the uterus as one cavity and gives 
Table 2. Zerbi's main works

Questiones Metaphysicae

impressum Bononiae per Johan de Nordlingen en Henric. De Harlem socios, anno salutis 1482, Kalen. Decembr., sedente Sixto IV, Pont. Max. 'anno eius duodecimo'. Quarto piccolo (small)

Small Gothic print. Total folios 512, in 12 books

Gerentocomia, opus quod de senectute agit

Gabrielis Zerbi Veronensis as Innocentium VIII. Pont. Max. feliciter incipit. Impressum Romae per Eucharium

Silber alias Frank, anno domini 1489 di vero Veneris 27, nonis novembris

Small Quarto, 2 columns, gothic types, folios 128 (unnumbered) with register. 57 chapters in total. The first complete medical treatise on old age, in barbarian Latin

De cautelis medicorum

Opus perutile editum a clarissimo philosopho ac Medico Magistro Gabriele Zerbo Veronense Theroricae Medicinae ordinarium Studii Patavini publice legente anno Domini 1495. Padua, Dominicus Berthonus, 1495, 1503, Pavia 1508, 1517 (M. Jacob. De Burgophranco), Lyon 1525, 1582, Pavia 1528, 1598, Christophorus de Pensis, Venice post 1495

Liber Anathomiae corporis humani et singulorum membrorum illius

Editum per Excellentiss. Philosophum ac Medicum Dom. Gabriele De Zerbis Veronensem. Venetis per Presbyterum Bonatum locatellum Bergomensem expensis heredum Nobilis Viri Domino Octaviani Scoti Civis modoetiensis anno domini 1502, 9. ${ }^{\circ} \mathrm{kal}$ Januarias. Folios $219+1 / 2$

\begin{abstract}
Second Edition
Opus praeclarum anathomiae totius corporis humani et singulorum membrorum illius editum ab excell. Domino Gabriele Zerbo Veronensi inter famosiores philosophos ac medicos latinae linguae clarissimo, nuper correctum et auctum cum tabula omnium capitulorum in fine opposito. Impress. Venet. Apud Octavianum Scotum anno Domini 1533, VII. Kal. Octobris. 234 folios in total. Small gothic print

De anatomia infantiis et porci ex traditione Cophonis, Marburg, Eucharius Cervicornus 1537 with Johannes Dryander, Anathomiae, hoc est corporis humani dissectionis pars prior Anatomia Matricis pregnantis et est sermo de anathomia et generatione embrionis

14 folios, which constituted the closing section of the book on anatomy. Printed in Marburg in 1537 and in Venice, 1592
\end{abstract}

Libellulus de Preservatione Corporum a Passione Calculosa

Manuscript Biblioteca Civica Verona No. 775, Cl, Medic. 91, 1, Busta A.

130 folios (A translation by Touwaide and De Santo, in preparation)

a description of the tubes. He masters on uterus ligaments (Nam in utroque duorum cornuum penetrat aliquid quod ex ipsis testiculis nascitur, cui officium est in vas mulieris seu matricem expellere sperma, quampropter ipsa amboduo spermatis expulsoria). He also gives an exact description of urinary bladder and eliminates the intermediate cavity of the heart described erroneously by Mundino. He precedes Achillini in describing the first part of the olfactorial nerve. $\mathrm{He}$ also has a primacy in making clear that intercostal nerves derive from the $\mathrm{V}$ and anastomizes with the pterygoid nerve.' The approach to Zerbi's anatomy was praised by Medici [9] who extensively adopted de Renzi's authority in his Scuola Anatomica di Bologna.

Lind [7], Department of Classics at the University of Kansas, in his masterpiece dedicated to 'Studies in PreVesalian Anatomy' in the pages on the Veronensis, was attracted by folios $5 \mathrm{r}$ and $87 \mathrm{r}$ where Zerbi takes up a proportion of the human body and nicely points out that it is a pity that also a genius once errs, as it occurred to Panofsky who, in his 'Meaning of visual art', failed to recognize him. In fact Panofsky quotes only Galen. However for Lind, Zerbi is the sole pre-Vesalian anatomists who deals with anthropometry, a discipline which goes back to Polyclitus, founder of Greek anthropometry. According to Lind, Zerbi learned from Vitruvius.

Haller in the 'Biblioteca Anatomica' discussing Zerbi's anatomy writes, 'Vastum opus adeo gothice impressum, siglis adeo incommodis et dictione ita barbara ut laborem legendi numquam potuerim sustinere, cum praeterea ea capita quorum legendorum toedium exhause merae fuerint compilationes non quidem hominis ignari, aut giudicio destituta apud quam utilia aliqua passim Morgagni detex- $\overline{168} \quad \overline{\text { Am J Nephrol 2002;22:164-171 }}$
Gaspare De Santo/Bisaccia/De Santo/ Touwaide 


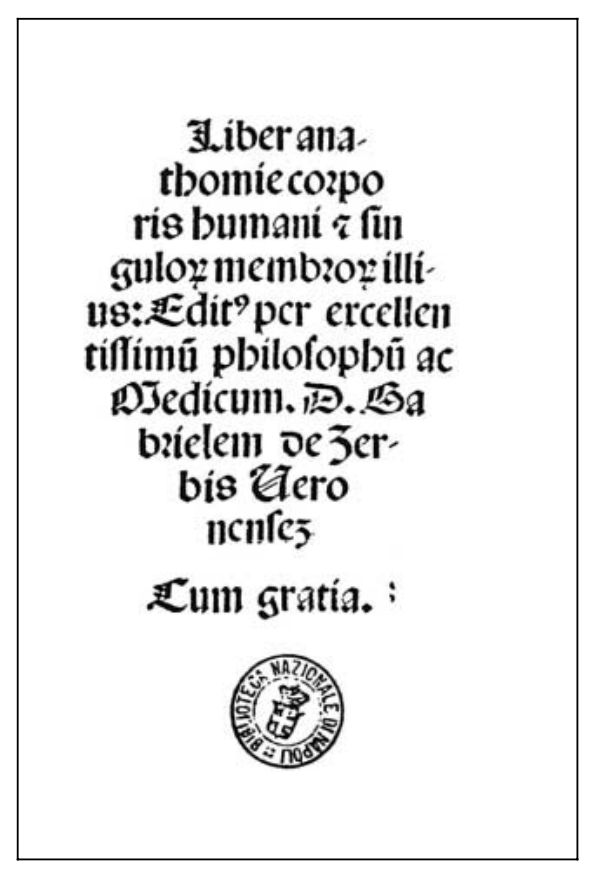

Fig. 6. Front page of Zerbi's anatomy.

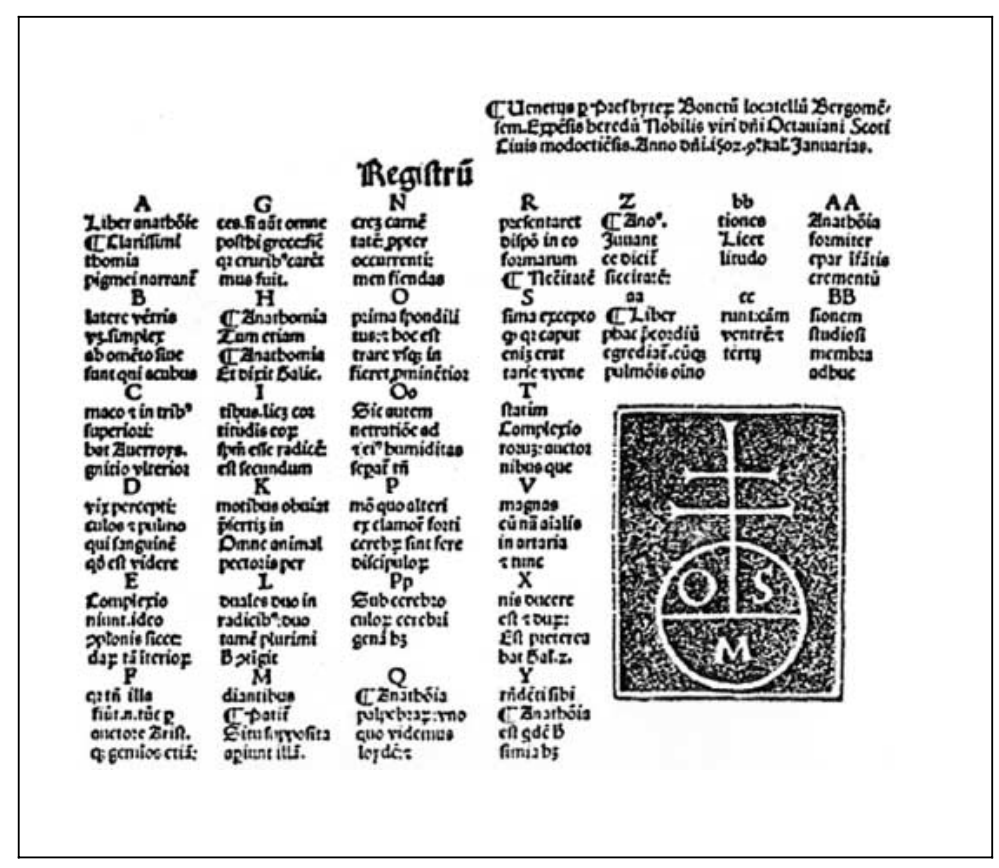

Fig. 7. Last half page of Zerbi's anatomy which includes place of printing, day of printing and register. it. Historiam habet cadaveris incorrupti Tulliae. Nervum olphactorium inter nervos recepit.'

According to Garrison [13], 'the continuum between Mundino and Leonardo is filled in part by the anatomist Gabriele Zerbi who first separated the organs into systems, was the first to treat infantile anatomy and to describe the muscle of the stomach and the puncta lacrimalia.' A concept, 'helping to fill in the continuum from Mundinus and Leonardo to the moderns was Gabriele Zerbi, who was the first to separate the organs into systems and to describe infant anatomy'; also supported by Hardaway Meade [14]. Cervetto [10] provided a careful and long analysis of Zerbi's anatomy where merits and errors are discussed with competence. Just because of the topic of this presentation it is appropriate to mention that on Zerbi's description of the urinary tract he came to the conclusion that 'information on the kidney are wrong and ridiculous, while the description of urinary bladder is good' (sui reni non dice che delle falsità o ridicolaggini ... ma descrive bene la vescica).

The Pre-Vesalian Kidney:

Gabriele Zerbi, 1445-1505

\section{The Kidneys}

The kidneys are described from f.34 recto to f.36 verso. In folio 34 recto we have only the incipit 'Anathomia renum que grece dicunt nephros: auctore Polluce. Inde passio nephretica: nephritis dicta est: nephretici in renibus patiunt'. Here we report some passages appearing in f.35 verso col.1 and col.2 which are relevant since they were commented by Berengario da Carpi (fig. 8). Carpi's comment (fig. 9) therefore immediately follows Zerbi's text.

\section{Col.1}

\section{TEXTUS}

Qualiter autem he vene renibus nutrimentum deferentes ad eorum substantiam terminentur, recte docebat Ari 3. de partibus, dicens: Meatum quid ex vena praetendit, non concavum subit renum, sed in eorum corporibus absumitur. Quamobrem in cavis renum nihil sanguinis continetur, neque concrescit, it est, coagulatur mortuis. Non nam diffunduntur vene per totam renum substantiam, sed per aliquem solum partem ut forte lateraliter. Secundum Conciliatorem neque in medium: ut sanguis paulisper et paulatim ceu in vaporem mutatus convertatur in eosdem. Sic diximus. Propter quod in eorum concavitate non sit sanguis, neque coagulatur sanguis morientium. Sed quicquid ita sancitum sit apud sapientes, sensu tamen comprehendimus in anathomia quod una venarum emulgentium excarnata, et stilo vel tenta in eo imposita, ad concavitatem et cavernositatem renis pervenit, ubi est panniculus ille in quo sequestratur aquositas a sanguine. Id etiam evidentius apparet si alter renum scin- 


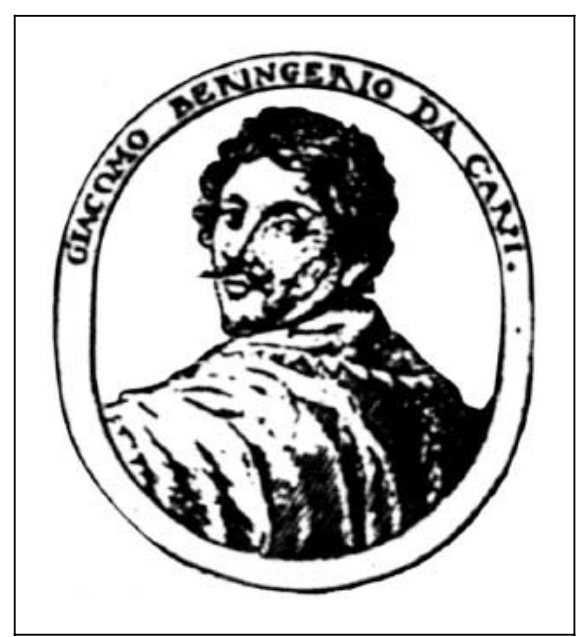

Fig. 8. Berengario da Carpi.

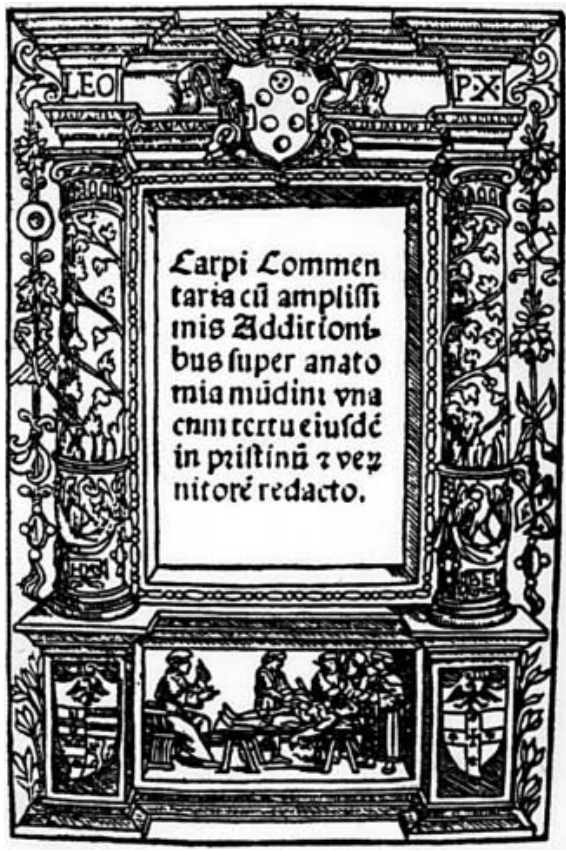

Fig. 9. Front page of Carpi Commentaria.

datur in parte eius convexa per longum trahendo quousque concavitas appareat. Tunc nam inveniemus panniculum illum quem diximus, rarum quod proculdubio non est al.iud quod vene emulgentes intrantes substantiam renum subtilitate et rarefacte in similitudinem colatorii sive cribri ut comuniter dicitur. Et ad formam panniculi contexte, per cuius porositates - sive foramina - urina egredi potest quod subtilis - non autem sanguis (quod grossior). Urina itaque hoc modo colatur inferius distilans in renibus ad orificium cui continuatur porus uritides descendens inferius usque ad vesicam, donec co- niugatur illi coniunctione mirabili. Et hec appellabat Gal, 4 de uti partium, cap 6 orificia renum emittentia que a fimis renum explantantur $\mathrm{Ab}$ unoquoque eorum unum. Et sunt meatus quidam de cavis renum exangues duo insignes auctore Arist. 3 de partibus qui ad vesicam feruntur

\section{ADDITIO}

Et ex hoc apparet error quorundam qui dicunt contra veritatem ad experientiam non reperire talem panniculum in concavitatate renum. Qui nam vidit, testimonium illis praehibuit. Et testimonium eius est verum.

Non consonat praeterea dictum auctorum quod comuniter scribitur. Si quod in venis emulgentibus taliter subtilitatis et per substantiam renum disseminatis sit sequestratio aquositatis urinalis, non quidem simpliter a sanguine. Sed illius tamen partis quae transire de per nutricationem renum, quam - ut dicunt - modicissima pars et sanguinea, transit intra rene per poros uritides ad vesicam ... cum urina. Partim ad nutricationem dictorum pororum et partim vesice. Sed neque hoc inventum est scribi ab Avi. in anatohimia renum neque in ea quae est vesice. Quomnino oppositum huius docebat ipse 19 tertii cap. de signis mictus sanguinis a sancii his verbis 'Vesice advenit aquositas colata, scilicet ex renibus. Sanguinem vero nutrimenti recipit vesica ex venis parvis in quibus venit ad eam nutrimentum tamen, quod non est in eis sanguis exuberans Et ad renes quidem venit sanguis plurimum cum aquositate.'

Col.2

Colatur ... apud eos aquositas. Et adveniunt eis, scilicet renibus, vene magne, ex quibus membra alia nutrimentum sumunt sugendo, scilicet de sanguine, quod ad eos venit cum aquositate.

\section{Text}

\section{Column 1}

How these veins bringing food to the kidneys ends in their substance has been correctly said by Aristotle in book 3 of the parts of animals. The orifice that opens at the end of the vein, does not enter into the concavity of the kidneys, but is assimilated into their body. For this reason, no blood is contained in the cavity of the kidneys, nor does it become concrete (that is, solid) in dead bodies. Veins are not diffused through the whole substance of the kidneys, but only in some limited part, as perhaps on the periphery. According to Conciliator they are not even in the center of the kidneys, so that the blood progressively and slowly converted into vapor is transformed into themselves. This is what we say. For this reason, there is no blood in their concavity, and blood does not even coagulate in the body of dying people. Whatever the opinion of learned men, we understand it by our senses in doing dissections. That is: if one of the percolating veins is cut and if we introduce a knife or a band into it, it arrives to the concavity - or hollow - of the kidney, where is the coat where the water of blood is extracted out of the blood. This appears even more evidently if the other kidney is cut in its convex part through its length until a concavity appears. Then, we shall find the coat of which we have said it is rare, because there is no doubt that it is nothing else than the percolating veins coming into the substance of the kidneys, in a subtle and tiny way, like a colatorium - or filter in common terms. Thanks to the shape of the coat inserted into the substance of the kidneys, urine can get out through their pores - or holes - because it is subtle, while blood cannot come out, because it is thicker. Urine is distilled in that way and brought down to the orifice continued by the urinary channels; then, it goes down until the bladder, until it is retained there by an admirable retention. Galen called
Gaspare De Santo/Bisaccia/De Santo/ Touwaide 
these orifices of the kidneys 'emitting orifices' which are connected at the bottom of the kidneys. There is one from each one of the kidneys. And these two visible channels that go from the cavity of the kidneys to the bladder are deprived of blood, according to Aristotle in the 3rd book of parts of animals.

\section{Addition}

From that, appears the error of those who say, against the truth, that such a coat cannot be found by experience in the cavity of the kidneys. The one who saw should testify to these people and his testimony will be true. Something which is generally written by some authors does not concord. If some water appears in the percolating veins and some urinary water is contained in the substance of the kidneys, it does not simply come from blood. But, of this part that passes through the kidneys for their nourishment - according to what they say -, only a small is made of blood. It crosses the kidney through the urinary channels, and goes to the bladder with urine. A part is destined to the nourishment of these channels and a part to that of the bladder. But not even that can be found written by Avicenna in the anatomy of the kidneys and not even in that of the bladder. He himself taught exactly the contrary in chapter 19 of the 3rd book, on the signs of the emission of blood and pus. These are his words: "A filtered water arrives to the bladder, that is, from the kidneys. The bladder receives blood as food from small veins through which it comes to nourish it, too, because there is no blood remaining in it. A high quantity of blood arrives to the kidneys, with water.'

Zerbi therefore started with the authority of Aristotle and made clear that veins do not enter the kidneys but only reach their periphery and stated that according to Pietro da Abano (Concilator) the veins do not enter in the center of the kidneys while blood is slowly converted into vapor. Zerbi also demonstrated that there is a filter (cola- torium) where urine is passed, while blood which is thicker, is stopped.

Berengario da Carpi in turn, made clear that he did not trust Zerbi when he wrote that veins do not enter the kidneys. He also made clear that, with the support of Avicenna, it is possible to exclude the existence of a filter. In this also Mundinus is wrong. Since Zerbi even wrote that he was able to see the filter and also because other scientists tried to conciliate both hypotheses, Berengario was therefore obliged to study the problem by experience and his studies did not support Zerbi's conclusions. Finally Berengario accused Zerbi of missquoting Galen on the role of the renal veins in extracting juice from gut and intestines and stressed that he was unable to trace in Galen that information.

In conclusion Zerbi was a talented scientist with a vast cultural background who gave extraordinary contributions to pre-Vesalian anatomy, a contribution acknowledged by many authorities in the field.

\section{Acknowledgements}

Aided by grants from Agenzia Spaziale Italiana, Regione Campania, Second University of Naples. The authors express appreciation to Prof. Silvana Favaro, University of Padova for many useful informations and suggestions. Thanks are also due to the Library of Mazzini Institute, Naples and to its Director Fr. Marisa Ursano.

\section{References}

1 Dallari U: I rotuli dei lettori legisti e artisti dello studio bolognese dal 1384 al 1799,3 vol. Bologna, Merlani, 1888, vol I, pp 97-118.

2 Tiraboschi G: Storia della Letteratura Italiana, Tomo VI, Parte II. Venice, Molinari, 1823

3 De Zerbis G: Questiones metaphysicae. Bologna, Johannes de Nördlingen et Henricus de Harlem, 1482.

4 Zerbi G: Gerontocomia, opus, quod de senectute agit. Impressum Romae per Eucharius Silber alias Frank, anno domini 1489, di vero Veneris 27, nonis novembris.

5 Dupuigrenet Desroussilles F: L'Università di Padova dal 1405 al Concilio di Trento, in Storia della cultura veneta, II vol. Vicenza, Pozza, 1980 , pp 622-623.
6 Romagnoli G: Contributi alla biografia di Gabriele Zerbi desunti dal suo testamento del 1504, in Pagine di Storia della Medicina, 1967; 11:99-110.

7 Lind LR: Studies in pre-vesalian anatomy Biography, translations, documents. Philadelphia, American Philosophical Society, 1975, pp 141-156.

8 Sanuto M: I Diarii. 39 vol, G. Berchet, Ed, a spese degli editori, 1879. T. II, III, V, VI.

9 Medici M: Compendio Storico della Scuola Anatomica di Bologna. Bologna, Tipografia Governativa della Volpe e del Sassi, 1857.

10 Cervetto G: Frammento storico di alcuni illustri anatomici italiani del XV secolo. Verona, Antonelli, 1842, pp 10-45.

11 De Zerbis G: Liber anathomie corporis humani et singulorum membrorum illius, Venetiis, 1502 .
12 De Renzi S: Storia della Medicina in Italia, ed 2. Naples, Tipografia del Filiatre-Sebezio, 1845 .

13 Garrison FH: An Introduction to the History of Medicine. Philadelphia, Saunders, 1953.

14 Hardaway Meade R: An Introduction to the History of General Surgery. Philadelphia, Saunders, 1951.

15 Berengario I: Carpi Commentaria cum Amplissimis Additionibus super Anatomia Mundini una cum textu eiusdem in pristinu et verum nitore redacto. Bononiae, Impressum per $\mathrm{H}$. de Benedictis, 1521.

16 De Santo NG, Bisaccia C, De Santo LS, De Santo RM, Di Leo VA, Papalia T, Cirillo M, Touwaide A: Berengario da Carpi. Am J Nephrol 1999;19:101-114. 